\title{
Export Diversification Journal. A Tool for Economic Growth. A Case Study of Selected Sub-Saharan African Countries
}

\author{
Okpara Ikechukwu John ${ }^{1} \quad$ Iloka Chinenye Ebele ${ }^{2}$ \\ 1. Federal University Otuoke \\ 2. Planning and Research Department, National Population Commission of Nigeria
}

\begin{abstract}
Export diversification was highlighted by the works of Hesse, 2008 and strauss-khan, 2011 by stating the importance of it. And they stated that an increase in export diversification will lead to increase in the gross domestic product of countries. Though, previous studies have shown that less developed nations likes those in Africa concentrate more on the export of single product which in most instances does not favour them. This is further understood by the report from the United Nations Conference on Trade and Development (UNCTAD) which reflects that the level of export concentration by the less developed nation leads to unstable/ lopsided way of growth. Sources of major revenue for some developing nations are derived from the production, sales and export of primary products. This makes them experience distortions in economic plans because of the irregularities in the world demand for goods and services. This work brings to light the importance and need for export diversification and some countries like; Angola, Cameroon, Mauritius, Namibia, Nigeria and South-Africa were studied between 1995-2015 using indices like exchange rate, labour force, export of goods and services and gross capital formation which were studied and analyzed to determine the impact of export diversification on GDP per-capita growth in these selected countries on one part and to determine the impact of export diversification on the terms of trade of these countries selected. Results from the SUR regression that was run revealed that there exists a linear relationship between the dependent and independent variables of the cross-sectional entities/ units. The result of the Johansen normalization test also revealed/indicated that the independent variables (exchange rate, export of goods and services and gross capital formation) are all positively related to the dependent variable (gross domestic product). From the outcome, export diversification seems to best suit developing nations especially those that are focused in this study.
\end{abstract}

Keywords: Export Diversification, Export Concentration, Exchange Rate, Gross Capital Formation, SUR (Seemingly Unrelated Regression), Labour Force.

DOI: $10.7176 / \mathrm{JESD} / 10-21-07$

Publication date: November $30^{\text {th }} 2019$

\section{Introduction}

Most developing countries in sub-saharan Africa get their revenues from exports of primary products that is why they experience fluctuations in their incomes and this is partly true because the world demand for primary products are irregular. That is why some authors claims that poor economic performance is attributed to export concentration. Just like in the past crude oil production and concentration in export was seen as dutch disease in Holland and a resource curse because of the fluctuations in development and vulnerability of those export concentrated countries that is caused by shocks in the price of the product in the international market. Although, Lederman and Maloney, 2007 explained that no proof exists that supports resource curse in the research they carried out in the Australian continent and in parts of Europe. Gylason (2001) found that there exist an opposite correlation between education and resource availability for natural resource based countries and these countries may be sluggish in investing in resources that are labour oriented. There exist similarity between sub-saharan African countries' resources in terms of their level of income, output, population and export products that is why they are categorized according to World Bank Outlook as: exporters of crude oil, middle-income countries and countries with little income (the fragile countries- category where majority of the African countries fall into).

In sub-saharan part of Africa some countries have really intensified the need to diversify in export of other products and these countries include South-Africa, Mauritius and Namibia according to Sanjay (2011). In recent times, export diversification in sub-saharan Africa has been seen to be a way of moving countries towards economic growth. This is so because price instability for primary export goods/products and general fluctuations and unstable plans will be averted. Benefits from export diversification includes boosting the capital base of a nation, improvement in the quality of output due to positive externalities, increase in employment and per-capita income; all of these mentioned above and more leads to economic boom all things being equal. The study of the variables used in this work, its application through seemingly unrelated regression (SUR) and the result derived revealed that increase in export diversification tends to improve the economy as explained by Nouira Plane and Sekkat, (2009) that regular variations in the prices of primary goods and barrier to trade internationally disorganizes/distorts planned economic activities that is why export diversification on secondary products is mostly proposed for developing economies like the sub-saharan African countries under focus. 
The countries in focus in this study are categorized in two parts; one group are those countries that are major exporters of a particular primary product (export concentrated countries) and the other group are seen as export diversified countries. The area of the continent of Africa that is geographically lying south of the sahara desert is regarded as sub-sahara Africa. The selected sub-saharan African countries in focus includes; Angola, Cameroon, Mauritius, Namibia, Nigeria and South Africa (Rosengerg A, 2015).

\subsection{Scope of Study}

The relationship that exists between economic growth in the selected sub-saharan African countries and export diversification between the years 1995-2015 is what this work tries to determine with the use of Seemingly Unrelated Regression (SUR) model. The countries that are considered in this research includes; Angola, Cameroon, Mauritius, Namibia, Nigeria and South-Africa. The data from the world development index on exchange rate, labour force, export of goods and services, gross capital formation and gross domestic product from 1995-2015 were used for this study.

\subsection{Relevance of Study}

This work is relevant in the sense that the importance of diversification through which growth is actualized. The volatile nature of some sub-saharan African countries' exports was noticed in this research and the ways through which the volatility can be reduced was highlighted as well. This study also brings to light the need of the selected sub-saharan African countries to improve on the level of manufacturing of products for export and not exporting of primary products alone. This work will also serve as a reference material for future research work.

\section{Literature Review}

\subsection{Conceptual Literature}

Among many definitions of export diversification only a few definitions are considered which include; definitions of Alwang and Siegel (1994) and Amin Guiterez de pineres and Ferrentino stated it as the improvement of export portfolio of a country from primary and intermediate goods.

Economic growth

Economic growth implies expansion of a country's national income or expansion of goods and services. Economic growth involves a combined procedure of changing of say production structure in the line of manufacturing and export of industrialized, finished and semi-finished products. The level of responsiveness of demand for exports of manufactured products in the market to change in income is necessary for growth in an economy. Some researchers identified that the standard of living can be determined by the state of the gross domestic product.

Nurkse stated that growth of an economy takes stability from two divides; which are unbalanced and balanced growth that are measured in different ways via these signals - the level of per-capita income, employment, output and gross national income. And so is the stages of economic growth which can be actualized though; improved terms of trade and balance of payment, even distribution of resources, infrastructural improvement and increase in national products, per-capita income increases, political stability, good tax policies and so on.

Export Diversification

Export diversification implies the conversion of a country's structure of export or changing the group of products through the technology level. It was also defined as the broading of different goods which a country exports by Dennis and Shephard (2007) and they classified export diversification into horizontal and vertical export diversification which implies variation in primary export combinations coupled with increase in export trade and processing through available new technology respectively. Samen (2000) thus explains the existence of a positive relationship between export earnings and export diversification.

Export Concentration

Export concentration means sole dependence in the production /extraction and export of one particular possibly primary product in the international or home market. It is also referred to as domination of one primary product for export by a country that trades with few international communities. But a diversified export country trades with many countries and have a variety of products to trade. Simply put, export concentration means monitoring a single export bstructure for export.

\subsection{Theoretical Literature}

New growth theory

The new growth theory deals with the growth that is enhanced by increasing returns that is caused to a large extent by new set of knowledge which can be gained externally (through international trade relationships). To better understand the new growth theory, Romer, 1990; Barro 1991; Sachs and Warner 1995 stated in their work that benefits which accrue from export trade may increase revenue, increase employment of skilled and unskilled workers internally and enhance advancement in management skills and improvement in technology for production externally all in the bid to improve the economy. 
Herzer and Lahman (2006) is of the opinion that export diversification can push an economy into growth because it tends to have a positive effect on economic growth by way of reducing dependence on primary product export. The channels through which export diversification can affect the growth of an economy include the portfolio effect which involves stabilizing of export revenue. This stability can be achieved through export diversification where fluctuations in the prices of primary products does not necessary distort the economy. That is why Agosin (2007) stated that countries that are export concentration are likely to experience reduced level of economic growth if fluctuations in prices persist. Countries offering few export products might find it difficult to reinstate itself to a favourable state when there is worldwide boom after a recessionary period. The economy of South Africa is a practical example of an economy that does not solely depend on a particular export good for a source of revenue. That is why Sarah 2005 in his work stated that concentration in primary product is export leads to unfavourable terms of trade for developing economies when relating to concentration in manufactured products. Du plessis, Smith and McCarthy (2000) explained that the conservative method helped in protecting the new iron and steel company as well as the mining sector by applying import substitution and imposition of tariff for the study country.

Endogenous Growth Theory

According to Dornbusch, Fischer and Startz (2008), a country is made better in terms of human capital accumulation if it produces what it can produce efficiently bearing in mind the comparative advantage for production of that particular product. Adam Amith (1776) and David Ricardo (1817) also laid some emphasis on the benefit of comparative advantage in production. Mayer (1996), believes that there exist a positive effect on accumulation of human capital in a country is witnessed due to the fact that the theory of endogenous growth stipulates for enhanced level of export diversification. This theory so states that growth of an economy is dependent on productivity improvement thus human capital growth which is achieved via the diversification of exports and import substitution.

Traditional Trade Theory

The theory of traditional trade speaks of the trades that are carried out in the early days where the mercantilists advocated for export expansion and promotion in exports in-order to obtain power and wealth. These mercantilists also ventured into the shores of Africa and so colonized Africa. The benefit a country derives from producing a particular commodity over another commodity is what the traditional comparative theory talks about. Most traditional trade theories explain that increase in returns and benefits from large scale production are key to favourable balances in the international scene.

As countries advance, trade liberalization became the order of the day and it shows when countries that are enjoying full benefits of exportation, meticulously considered liberalization before participating, changing the structure of their institutions. Experienced nations try to reduce the adverse effect of liberalization in trade on the people by embarking on researches in-order to determine the importance of this policy on the masses.

Portfolio and Portfolio Effect Theory

The concept of portfolio theory was developed by Pro. Harry Markowitz; he explained the need not to overdependence on the production and export of solely primary products. So did Love, J (1979) explain the benefits that are attached to diversification/reduced export concentration through the knowledge of portfolio theory. The study of the theory of portfolio effect explains that the relationship that exists between growth of an economy and export basket; considering the yield that will be gotten from the concentration in an export product and the level of volatility in international market. Therefore, the earning instability that is experienced does not create a planned and balanced economy. And in stating the theory of export diversification under the portfolio effect theory entails improved export earnings and stable growth conditions (Paulo, 2013).

Agosin (2009) explains portfolio effect as a way of establishing positive correlation that exists between economic growth and export diversification when considering developed countries. An engagement of an effective export diversification will lead to the reduction of the level of volatility that was hitherto witnessed; which leads to faster growth. According to Chaudhuri (2001), it has been observed in the past that diversification in export is a medium through which growth and development is achieved that is why the international community expressed dilemma of the volatile prices of primary products and low elasticity of demand for these primary products some subsaharan African countries. In the 1960s economists found empirical proof against export concentration after testing the relationship between export diversification and economic growth in less developed sub-saharan countries which shows that major commodities for export are primary in nature leading to economic instability in these countries (Massell, 1964; Mac Bean \& Nguen, 1980). A research executed by Maizels (1968) shows a relationship between gross national product and economic fluctuations. The result of this relationship is in the form of ineffective economic planning, inflation, inappropriate speculation and miscalculations are the effects of economic instability that causes fluctuations that are experienced in export of primary products that are exported by developing countries especially.

Theory of Dynamic Effects

In the theory of dynamic effect, diversification in exports leads to externalities like skills/knowledge, expansion 
in infrastructure which leads to productivity and growth. The theory expresses the relationship that exists between economic growth and diversification in exports which magnifies the importance of growth that is led by diversification of export in countries. Firebaugh and Bullock (1987), the dynamic effect theory is explained in form of a queue with the expansion of exports ending the line which leads to improved ideas in production/knowledge as well as invention of new modern companies leading to more output for exportation. A conclusion from the linkages that exists from the theory identifies the benefits that are explained from the theory of dynamic effect. Productivity is enhanced by the knowledge acquisition which is as a result of increased export; the dynamic effect theory involves a correlation between exports and productivity. That is why scholars like Jensen and Benard (1999) states that exporters benefits more than the non-exporters in terms of overall gains. According to Herzer and Nowak-Lehnman 2007; Van Biesenbroek 2005 explains that the disparity that is experienced in the earnings, technology, revenue and overall growth of developed and developing countries is as a result of how well these countries utilize their productive resources.

The production capacity of companies of nations that are export diversified is improved/ enhanced owing to the knowledge acquired through inter-trade between importing and exporting countries. Diversification of production and exports can be horizontal or vertical. It is also advocated for the combination of horizontal and vertical diversification for the expansion of output, infrastructure, knowledge (spillovers) thus improve the economy. So did Lederman and Maloney argue that diversification in exports is one of the reasons for improved growth of countries therefore increasing the spread of development generally. It is important to know that export diversification alone is not the reason for the level of growth being witnessed by states. The economy of Mauritius diversified into secondary products has been the efforts of investors and the government towards achieving improved economy.

\subsection{Research Gap}

The works of many authors like; Sviotti and Frenken (2008), Amin Guitierez dePineres e.t.c wrote on export diversification and concentration in exports and also reflected on the relationship that exists between export concentration and economic growth but did not focus on the selected countries that are being considered in this work. And the comparism (cum) relationships that exists between export diversification and growth is seen more clearer in this research work when the comparism is done between selected sub-saharan countries viewed as liberal in their exports (export diversification) and those countries that are export concentrated.

\section{Theoretical Framework}

The theory of dynamic effect underlies this work so did the theory portfolio effect. They in one way or the other describes the correlation that exists between the growth of an economy and concentration or diversification in exports. Though, emphasis were made on the forward linkages and learning externalities that the dynamic effect theory proposes according to the works of Herzer and Nowak Lehnmann, 2006; Hirschman, 1968. These underlined theories are important because it tends to explain that through export diversification; the growth level of a country increases bearing in mind the portfolio of exports which will affect the export earnings, level of volatility, revenue and infrastructural facilities.

\section{Model Specification/ Descriptive Analysis}

In capturing the objectives of this work which tends to determine the relationship that exists between export diversification and economic growth measured by the GDP per-capita. The model below is specified for this purpose.

$$
\begin{aligned}
& \text { GDPexdiv }=B_{0}+B_{1} l f+B_{2} e g s+B_{3} e r+B_{4} g c f+E_{i t} \\
& G D P t o t=C_{0}+C_{1} l f+C_{2} e g s+C_{3} e r+C_{4} g c f+U_{t i}
\end{aligned}
$$

The variables used in the model above include; gross domestic product (GDP) as the dependent variable while gross capital formation (gcf), export of goods and services (egs), labour force (lf) and exchange rate (er) as independent variables. This work also considered the economy of Nigeria, South Africa, Angola, Cameroon, Namibia and Mauritius from $1995-2015 . B_{i}$ and $C_{i}(i=0,1, \ldots \ldots, 4)$ in the model above are the parameter coefficients and $\mathrm{E}, \mathrm{U}$ are thr disturbance terms. Models 1 and 2 where $\mathrm{GDP}_{\text {exdiv }}$ implies the influence of export diversification on GDP per-capita while GDP tot implies the influence export composition have on terms of trade.

The data published in 2016 by the National Bureau of Statistics and World Development Indicator was utilized for this study. And the study countries where divided into two categories based on the export composition and the level of diversification. In analyzing descriptively the variables used, the gross domestic product measured by capital of individuals of the sub-saharan countries in focus, labour force that is engaged in the production process to enhance diversification in exports, exports of goods and services of each country under study measured as a percentage of the GDP which helps to determine the contribution that export brings to each country's GDP, the gross capital formation as a percentage of the GDP of each country entails the capital level that gross capital 
formation contributes to the GDP of the study countries and the exchange rate measured by the local currency per US dollars ; this also helps to tell benefits derived from trade between countries of these selected sub-saharan African countries under study.

The result of Levin, Lin and Chu unit root test reveals that labour force and export of goods and services are stationary under $5 \%$ and $1 \%$ level of significance. It also reveals the presence of unit root in GDP per-capita, gross capital formation and exchange rate but after first difference the result shows that the series robustly rejects the null hypothesis of the presence of unit root. Therefore the model regression equation becomes;

$$
\begin{aligned}
& \text { GDPexdiv }=B_{0}+B_{1} l f+B_{2} \text { egs }+B_{3} d(e r)+B_{4} d(g c f)+E_{i t} \\
& \text { GDPtot }=C_{0}+C_{1} l f+C_{2} \text { egs }+C_{3} d(e r)+C_{4} d(g c f)+U_{t i}
\end{aligned}
$$

In identifying the stationary long-run relationships that exists among the set of integrated variables, the cointegration test analysis is carried out. The Max-Eigen value and the trace test are the two tests that are applied to determine the relationship. To reject the null hypothesis of no co-integration using the trace statistics, the value of trace statistics has to be higher than 5\% critical value and that there exist a certain number of co-integrating relationships in the set of variables and vice-versa.

From the Johansen co-integration tests, it reveals three (2) co-integrated equatios at 5\%; note that the trace statistics value for maximum rank $0,1, \& 2$ are more than $5 \%$ critical value. In the Johansen co-integration test, the Max-Eigen value test indicates three (3) co-integration equations at 5\% level of significance. This reveals that there exists a long term relationship among the variables. To investigate the impact of export diversification on GDP percapita growth in selected sub-saharan African nations " $G D P_{\text {exdiv }}=\mathrm{f}$ (gcf, lf, export of gs, exchange rate)", the seemingly unrelated regression (SUR) was implored and the result shows that some of the variables in the model are significant. The coefficient of determination $\left(\mathrm{R}^{2}\right)$ which shows how much variation in the dependent variable is caused by the independent variable included in the model and the $\mathrm{R}^{2}$ of 0.4244 in the result shows that $42 \%$ variation in the dependent variable is caused by four independent variables that exists in the study.

\subsection{Test of Hypothesis}

It is shown from SUR that the coefficient of the estimated model is statiscally significant which implies a relationship that is between the dependent and independent variables. This tends to debunk the $\mathrm{Ho}_{1}$ of export diversification not having an impact on GDP per-capita growth in selected sub-saharan African countries. Results from the estimated SUR model and the error correction model for the second objective and hypothesis, shows that the coefficient of the vector error correction model is statistically significant. It invariably implies that there is a relationship between export of goods/ services and GDP per-capita for most sub-saharan African under study in the long-run. This means positive relationship between production, export of finished/ semi-finished product and in the terms of trade cum GDP per-capita increase and vice-versa.

\section{Summary, Conclusion and Recommendation}

The determination of the role export diversification play towards the GDP per-capita of the selected sub-saharan African countries from 1995-2015 is what this study is focused on. The SUR technique was used for estimation and it was realized that the independent variables were significant in explaining the dependent variable. Although some independent variables was found to be negatively related on the GDP per-capita in some countries under study. Due to the fact that the unit root test, the t-test, coefficient of determination does not have good results, the error correction model (ECM) was utilized in-order to correct the errors in the models to make the models/ results statistically significant. And so the regression result showed that there exists a positive relationship between GDP per-capita and gross capita formation, export of goods and services. The coefficient of determination of 0.4244 explains that, the independent variables in the model utilized explain about $42 \%$ changes in the gross domestic product of the selected countries studied. This means that changes observed in the independent variables tends to affect the GDP per-capita of the entities under study. From the Johansen normalization restriction, the model for the objectives reflects a positive correction between export of goods and services, exchange rate (er), gross capital formation (gcf) and gross domestic product; this implies that more these selected sub-saharan African countries diversify their exports it will lead to an improved GDP per-capita. Most of the control variables in the model is in conformity with the prio expectations because the impact of export diversification on gross domestic product stays positive and significant as expected. By implication means that the government of these selected countries are to benefit from export diversification they have to support the local industries for better products and export of the products. But in the case of inadequate funding for the production of finished goods and services the necessary results will not be achieved.

In conclusion, the results from the analysis reveal that export diversification leads to economic growth. That is why a thorough and disciplined approach is required in order to diversify these countries' exports although specialization in specific export product that an economy has comparative advantage is encouraged if it is more beneficial but diversification in exports still seems to be the best for developing African countries that are endowed 
with multiple natural resources. The works of Naude and Rossow (2008), Amin Guiterrez de Pineres and Ferrantino were sources of inspiration to this study. The authors wrote on the roles export diversification play to the economy of Chile and South African respectively. Different tests were also carried out in the bid to get a research work free of bias and errors. These tests include; Unit root tests, co-integration test and the Descriptive statistics.

It is therefore recommended that modern technology on production for diversification should be advocated by these sub-saharan African countries so that highly competitive export products can be produced. It is also recommended that stakeholders in policy making and implementation of the policies should focus more on increased resource allocation towards production of those competitive products in these countries specified. In addition to these recommendations a business friendly environment should be established in these sub-saharan nations this work focuses on. This will help inspire these countries in the acquisition and application of the knowledge gained for the good of all sundry.

\section{References}

Acharyya, R. (2011). Export Diversification, Composition and Economic Growth: Evidence from cross-country analysis.

Acemoglu, A. (2012). Why Nations Fail: The Origins of Power, Prosperity and Poverty. Crown Business Division of Radom House. ISBN 9780307719226.

Agosin, M. R. (2007). Export diversification and growth in emerging countries.

Agosin, M.R., Alvarez, R and Bravo-Ortega, C. (2009). Determinant of export diversification around the world: $1962-2000$.

Agosin M.R. (2009). Export diversification and growth in emerging countries.

Al-Marhubi, F. (2000). Export diversification and growth: An empirical investigation. Applied Economic letters, 7 (9), 559-562.

Alwang, J., Siegel, P and Ali, R. (1991). Export diversification, export growth and stability: A look at three African countries.

Asli Demirgüç-Kunt and Ross E. L. (2010). "Financial Institutions and Markets across Countries and over time: the updated financial development and structure database," World Bank Economic review, vol .24, No. 1, pp. 77-92 (Washington: World Bank).

Baltagi, B. H, Feng, Q., and C. Kao (2012). "A Lagrange Multiplier test for Cross-sectional Dependence in a Fixed Effects Panel Data Model," Journal of the Econometrics, 170, 164-177.

Barro, R. J. (1997). "Determinants of Economic Growth: A Cross-Country Empirical Study,” MIT Press Books (Cambridge, Massachusetts: Massachusetts Institute of Technology).

Behrman, J. (1987). Commodity price instability and economic goal attainment in developing countries.

Bernard, A. B and Jensen, J.B. (1999). Exceptional exporter performance: Cause, effect, or both. Journal of International Economics, 47 (1), 1-25.

Besedes, T and Prusa, T. (2006). Explaining export diversification through innovation decisions.

Biesenbroek, J. V. (2005). Exporting raises productivity in sub-Saharan African manufacturing firms. Journal of International Economics, 67 (2), 373-391.

Blalock, G and Gertler, P. J. (2004). Learning from exporting revisited in a less developed setting. Journal of Development Economics, 75 (2), 397-416.

Breusch, T., and A. Pagan (1980). "The Lagrange Multiplier Test and its Application to Model Specification in Econometrics," Review of Economic Studies, 47, 239-253.

Cadot, O., Carrère, C and Strauss-Kahn. V. (2007). Export diversification: What's behind the hump? CEPR Discussion Paper No. DP6590.

Chaudhuri, K. (2001). Long-run prices of primary commodities and oil prices. Applied Economics, 33(4),531-538. Export Diversification and Growth in Sub-Saharan Africa.

Chenery, H. (1981). The changing composition of developing country exports.

Collier, P. (2006). African growth: Why a 'Big Push'? Journal of African Economies.

Coppock, J. D. (1962). International economic instability.

Dennis, A and Shepherd, B. (2007). Trade costs, barriers to entry and export diversification in developing countries.

Dornbusch, R., Fischer, S and Startz, R. (2008). Macroeconomics. (10th ed.). New York: McGraw-Hill Companies Inc Du Plessis, S. J. P., Smith, B. W., \& McCarthy, C. L. (2000).International economics ( $2^{\text {nd }}$ ed.).

Du Plessis, L. (2005). Free trade and competition policy in Africa: An Economic Society of South Africa.

Firebaugh, G., Bullock, B. (1986). Level of processing of exports: New estimates for 73 less-developed countries in 1970 and 1980.

Forgha, N.G., Sama, M.C., Atangana, E.M. (2014). The Effects of Export Diversification on Economic Growth in Cameroon. International Invention Journal of Arts and Social Sciences (ISSN:2408-7238)Vol.1(3)pp.5469,December,2014. 
Glezakos, C. (1973). Export instability and economic growth: A statistical verification. Economic Development and Cultural Change, 21 (4), 670-678. .

Gutiérrez-de-Piñeres, S. A and Ferrantino, M. (1997). "Export diversification and structural dynamics in the growth process: The case of Chile", Journal of Development Economics 52(2): 375-391.

Gutiérrez-de-Piñeres, S. A and Ferrantino, M. (2000). Export dynamics and economic growth in Latin America: A comparative perspective, Burlington, VT, Ashgate.

Gylfason, T. (2006). Economic Liberalization and integration policy. Natural resources, education and economic development.

Hammouda, H. B., Karingi, S. N., Njuguna, A. E and Jallab, S. M. (2006). Diversification : Towards a new paradigm for Africa's development. Addis Ababa, United Nations Economic Commission for Africa, African Trade Policy Centre.

Hausmann, R., Hwang, J and Rodrik, D. (2007). What you export matters. Journal of Economic Growth, 12 (1), $1-25$.

Hesse, H. (2009). Export diversification and economic growth. In R. Newfarmer, W. S. \& Walkenhorst, P.(Eds.), Breaking into new markets. Emerging lessons for export diversification (pp. 55-80). Washington, DC: The World Bank.

Herzer, D and Nowak-Lehmann, F. (2006). "What does export diversification do for growth? An econometric analysis", Applied Economics 38(15): 1825-1838.

Hirschman, A. O. (1964). The paternity of an index. The American Economic Review, 54 (5), 761-762 Export Diversification and Growth in Sub-Saharan Africa.

Hirschman, A. O. (1968). The strategy of economic development. New Haven: Yale University Press.

Hirsh, S. and Lev, B. (1971). Sales stabilization through export diversification and foreign marketing strategies.

Imbs, J and Wacziarg, R. (2003). "Stages of diversification", American Economic Review (93)1: 63-86.

International Monetary Fund, 2007a. Regional Economic Outlook: Sub-Saharan Africa (Washington, April), 2007b, Guide on Resource Revenue Transparency (Washington, October), 2009, Regional Economic Outlook: Sub-Saharan Africa (Washington, April), 2010, Understanding Financial Interconnectedness, electronically available, 2011a, Assessing Reserve Adequacy, IMF Policy Papers, (Washington, April), 2011b, Revenue Mobilization in Developing Countries, (Washington, April), 2012, World Economic Outlook, World Economic and Financial Surveys (Washington, April).

Jones, C. I. (2002). Introduction to economic growth (2nd ed.).

Klinger, B and Lederman, D. (2004). Discovery and development: An empirical exploration of "new" products, Washington, DC, World Bank Policy Research Working Paper 3450.

Koren, M. (2003). Financial globalization, portfolio diversification and the pattern of international trade: Diversification through trade.

Lederman, D and Maloney, W. F. (2003). Trade structure and growth. World Bank Policy Research Working Paper No. 3025.

Lim, D. (1976). Export instability and economic growth: A return to fundamentals. Oxford Bulleting of Economics and Statistics, 38 (4), 311-322.

Love, J. (1986). "Commodity concentration and export earnings instability: A shift from cross- section to time series analysis", Journal of Development Economics (24)2: 239-248.

Mac Bean, A. I. (1966). Export instability and economic development. Cambridge, Massachusetts: Harvard University Press.

Mac Bean, A. I and Nguyen, D. T. (1980). Commodity concentration and export earnings instability: A mathematical analysis. The Economic Journal, 90 (358), 354-362.

Matthee, M and Naudé, W. A. (2007). The determinants of regional manufactured exports from a developing country, Helsinki, United Nations University, World Institute for Development Economics Research (UNWIDER).

Massell, B. F. (1964). Export concentration and fluctuations in export earnings: A cross-section analysis. The American Economic Review, 54 (2), 47-63.

Mayer, J. (1996). Implications of new trade and endogenous growth theories for diversification policies of commodity-dependent countries.

Michaely, M. (1958). Concentration of exports and imports: An international comparison. An Economic Journal.

Mudenda, C,, Choga, I and Chigamba, C. (2014). The Role of Export Diversification on Economic Growth in South Africa. Department of Economics, University of Fort Hare.

Naudé, W and Rossouw, R. (2008). Export diversification and specialization in South Africa. Extent and Impact. UNU-WIDER Research Paper No. 2008/93.

Nurkse, R. (1961). International trade theory and development policy: A case for international specialization which is firmly based on considerations of economic efficiency.

Olaleye, O and Olasode, S. (2013). Export diversification and Economic Growth in Nigeria. An Empirical Test of 
Relationship Using a Granger Casualty Test.

Paulo, M. F. (2013). Diversification of the Angolan Exports - Challenges and Benefits.

Pesaran, M. H. (2004) "General Diagnostic Tests for Cross Section Dependence in Panels," University of Cambridge, Faculty of Economics, Cambridge Working Papers in Economics No. 0435.

Romer, P. M. (1990). "Endogenous technological change”, Journal of Political Economy (98)5: 71-102.

Ross, S. A., Westerfield, R. W and Jaffe, J. (2005). Corporate Finance (7th ed.). New York: McGraw- Hill.

Rose, A., and Spiegel, M. (2009). "Cross-Country Causes and Consequences of the 2008 Crisis: Early Warning," NBER Working Paper 15357 (Cambridge, Massachusetts: NBER).

Sachs, J. D and Warner, A. M. (1997) "Natural Resource Abundance and Economic Growth," The Center for International Development, (Cambridge, Massachusetts: CID).

Samen, S. (2010). Export development, diversification and competitiveness: How some developing countries got it right.

Sanjay, M. (1995). A review of problems in crude oil production and transportation.

Sarkar, P. (2005). Rising manufacture exports and terms of trade.

Saviotti, P and Frenken, K. (2008). Export variety and the economic performance of countries. Journal of Evolutionary Economics, 18 (2), 201-218.

Seemingly unrelated regression- Moon, Perron, July 2006.

Sekkat, M. (2000). Exchange rate management and manufactured exports in Sub-Saharan Africa.

Smith, A. M. ( 2009). 'Fair Trade, Diversification and Structural Change: Towards a Broader Theoretical Framework of Analysis', Oxford Development Studies, 37: 4, pp. 457-478. Third World Network (TWN), 2010, 'The financial crisis and challenges facing Africa.

Stanley, D. I and Bunnag, S. (2001). A new look at the benefits of diversification: Lessons from Central America. Applied Economics, 33 (11), 1369-1383.

Strauss-Kahn, V. (2011). Export diversification: What is behind the imbalances. A time series analysis of 156 countries over 19 years span.

Strobl, E. (2006). Export diversification and price uncertainty in Sub-Saharan Africa and other developing countries. A portfolio theory approach.

Syquin, M. (1986). Growth and structural change in latin America since 1960: a comparative analysis.

UNCTAD (2003). Economic Development in Africa, 2003. Trade performance and commodity dependence.

UNCTAD (2008a). Economic Development in Africa, 2008. Export performance following trade liberalization: Some patterns and policy perspectives.

UNCTAD (2008b). Trade and Development Report, 2008.New York and Geneva. http://www.unctad.org/en/docs/tdr2008_en.pdf UNCTAD (2010a). Commodity Price Statistics; Annual averages of free-market price indices (1960-2009).

Wagner, J. (2007). Exports and productivity: A survey of the evidence from firm-level data. The World Economy, $30(1), 60-82$.

Warner, J.( 2001). "Natural Resources and Economic Development: The Curse of Natural Resources," European Economic Review, Vol. 45, pp. 827-38. Saurina, Jesús, 2009, “Dynamic Provisioning,” World Bank Public Policy Journals, Note 7.

World Bank (2009). Pink Sheets. Data on historic commodity prices.

World Bank (2009). Global Economic Prospects: Commodities at the Crossroads (Washington: World Bank). 


\section{Appendix1. Regression using SUR}

\section{APPENDIX}

- sureg (iyke: gdppercapita = gcf labouforce exportsofgs exchgerate)

Seemingly unrelated regression

\begin{tabular}{|c|c|c|c|c|c|c|}
\hline Equation & Obs & Parms & RMSE & "R-sq" & chi2 & $\mathrm{P}$ \\
\hline iyke & 126 & 4 & 1868.962 & 0.4244 & 92.91 & 0.0000 \\
\hline
\end{tabular}

\begin{tabular}{|c|c|c|c|c|c|c|}
\hline gdppercapita & Coef. & Std. Err. & $\mathrm{z}$ & $\mathrm{P}>|\mathrm{z}|$ & [95\% Conf. & Interval] \\
\hline \multicolumn{7}{|l|}{ iyke } \\
\hline$g c f$ & 92.48901 & 34.9373 & 2.65 & 0.008 & 24.01317 & 160.9648 \\
\hline labouforce & -.0000465 & .0000154 & -3.02 & 0.003 & -.0000766 & -.0000163 \\
\hline exportsofgs & -53.23663 & 12.42653 & -4.28 & 0.000 & -77.59217 & -28.88108 \\
\hline exchgerate & -7.72767 & 1.069768 & -7.22 & 0.000 & -9.824376 & -5.630965 \\
\hline${ }_{-}$cons & 5283.336 & 1132.374 & 4.67 & 0.000 & 3063.923 & 7502.749 \\
\hline
\end{tabular}

- sureg (angola: gdppercapitaus = gcfofgdp labourforce expgsofgdp exchratelcupe $>$ rusperiodaverage)

Seemingly unrelated regression

\begin{tabular}{lcccccc}
\hline Equation & Obs & Parms & RMSE & "R-sq" & chi2 & P \\
\hline angola & 21 & 4 & 526.6618 & 0.9196 & 240.25 & 0.0000 \\
\hline
\end{tabular}

\begin{tabular}{|c|c|c|c|c|c|c|}
\hline gdppercapi s & Coef. & Std. Err. & $\mathrm{z}$ & $P>|z|$ & [95\% Conf. & Interval] \\
\hline \multicolumn{7}{|l|}{ angola } \\
\hline gcfofgdp & 20.32846 & 23.01001 & 0.88 & 0.377 & -24.77033 & 65.42726 \\
\hline labourforce & .0016985 & .0003273 & 5.19 & 0.000 & .001057 & .00234 \\
\hline expgsofgdp & .3904502 & 13.33488 & 0.03 & 0.977 & -25.74544 & 26.52634 \\
\hline exchratelc e & -7.111622 & 9.673374 & -0.74 & 0.462 & -26.07109 & 11.84784 \\
\hline _cons & -8925.973 & 2412.713 & -3.70 & 0.000 & -13654.8 & -4197.142 \\
\hline
\end{tabular}


- sureg (cameroon: gdppercapitaus = gcfofgdp labourforce expgsofgdp exchratelcu

$>$ perusperiodaverage)

Seemingly unrelated regression

\begin{tabular}{lcccccc}
\hline Equation & Obs & Parms & RMSE & "R-sq" & chi2 & P \\
\hline Cameroon & 21 & 4 & 23.10149 & 0.9928 & 2911.77 & 0.0000 \\
\hline
\end{tabular}

\begin{tabular}{r|rrrrrr}
\hline gdppercapi s & Coef. & Std. Err. & $z$ & P > |z| & [95\% Conf. Interval] \\
\hline cameroon & & & & & & \\
$\quad$ gcfofgdp & .6722702 & 5.051463 & 0.13 & 0.894 & -9.228416 & 10.57296 \\
labourforce & .0001766 & $9.55 e-06$ & 18.50 & 0.000 & .0001579 & .0001953 \\
expgsofgdp & 4.774514 & 2.742186 & 1.74 & 0.082 & -.6000719 & 10.1491 \\
exchratelc e & -1.076802 & .0931609 & -11.56 & 0.000 & -1.259394 & -.89421 \\
$\quad$ cons & 167.9633 & 98.14915 & 1.71 & 0.087 & -24.40553 & 360.3321 \\
\hline
\end{tabular}

- sureg (mauritius: gdppercapitaus = gcfofgdp labourforce expgsofgdp exchratelc

$>$ uperusperiodaverage

Seemingly unrelated regression

\begin{tabular}{lcccccr}
\hline Equation & Obs & Parms & RMSE & "R-sq" & chi2 & P \\
\hline mauritius & 21 & 4 & 415.1932 & 0.9688 & 652.46 & 0.0000 \\
\hline
\end{tabular}

\begin{tabular}{r|rrrrrr}
\hline gdppercapi s & Coef. & Std. Err. & $z$ & P > z l & [95\% Conf. Interval] \\
\hline mauritius & & & & & & \\
$\quad$ gcfofgdp & 9.512539 & 43.46688 & 0.22 & 0.827 & -75.68098 & 94.70606 \\
labourforce & .0841441 & .0078905 & 10.66 & 0.000 & .0686789 & .0996093 \\
expgsofgdp & -108.0029 & 25.09198 & -4.30 & 0.000 & -157.1823 & -58.82355 \\
exchratelc e & -234.4701 & 40.78936 & -5.75 & 0.000 & -314.4157 & -154.5244 \\
$\quad$ cons & -27283.31 & 5193.334 & -5.25 & 0.000 & -37462.05 & -17104.56 \\
\hline
\end{tabular}


- sureg (Namibia: gdppercapitaus = gcfofgdp labourforce expgsofgdp exchratelcu

$>$ perusperiodaverage)

Seemingly unrelated regression

\begin{tabular}{lcccccr}
\hline Equation & Obs & Parms & RMSE & "R-sq" & chi2 & P \\
\hline Namibia & 21 & 4 & 384.5228 & 0.9193 & 239.09 & 0.0000 \\
\hline
\end{tabular}

\begin{tabular}{c|rrrrrr}
\hline gdppercapi s & Coef. & Std. Err. & $z$ & P I I I & [95\% Conf. Interval] \\
\hline Namibia & & & & & & \\
$\quad$ gcfofgdp & 79.22536 & 30.32045 & 2.61 & 0.009 & 19.79838 & 138.6523 \\
labourforce & .0137716 & .0012804 & 10.76 & 0.000 & .0112621 & .016281 \\
expgsofgdp & -43.26425 & 24.19583 & -1.79 & 0.074 & -90.68721 & 4.158711 \\
exchratelc e & -369.1461 & 62.82415 & -5.88 & 0.000 & -492.2792 & -246.0131 \\
$\quad$ cons & -3703.302 & 1029.731 & -3.60 & 0.000 & -5721.537 & -1685.067 \\
\hline
\end{tabular}

- sureg (nigeria: gdppercapitaus = gcfofgdp labourforce expgsofgdp exchratelcup $>$ erusperiodaverage)

Seemingly unrelated regression

\begin{tabular}{lcccccr}
\hline Equation & Obs & Parms & RMSE & "R-sq" & chi2 & P \\
\hline nigeria & 21 & 4 & 196.3936 & 0.9626 & 540.94 & 0.0000 \\
\hline
\end{tabular}

\begin{tabular}{c|rrrrrr}
\hline gdppercapi s & Coef. & Std. Err. & $z$ & P > I I & [95\% Conf. Interval] \\
\hline nigeria & & & & & & \\
$\quad$ gcfofgdp & 61.41666 & 24.33516 & 2.52 & 0.012 & 13.72063 & 109.1127 \\
labourforce & .0001537 & .0000227 & 6.76 & 0.000 & .0001092 & .0001983 \\
expgsofgdp & -1.592528 & 6.631683 & -0.24 & 0.810 & -14.59039 & 11.40533 \\
exchratelc e & -6.144362 & 2.004093 & -3.07 & 0.002 & -10.07231 & -2.216412 \\
$\quad$ _cons & -5463.885 & 796.2956 & -6.86 & 0.000 & -7024.596 & -3903.175 \\
\hline
\end{tabular}


- sureg (southafrica: gdppercapitaus = gcfofgdp labourforce expgsofgdp exchrate

> lcuperusperiodaverage), isure

Iteration 1: tolerance $=2.030 e-13$

Seemingly unrelated regression, iterated

\begin{tabular}{|c|c|c|c|c|c|c|}
\hline Equation & Obs & Parms & RMSE & "R-sq" & $\operatorname{chi} 2$ & $\mathrm{P}$ \\
\hline southafrica & 20 & 4 & 585.1349 & 0.8808 & 147.72 & 0.0000 \\
\hline
\end{tabular}

\begin{tabular}{|c|c|c|c|c|c|c|}
\hline gdppercapi s & Coef. & Std. Err. & z & $\mathrm{P}>|\mathrm{z}|$ & [95\% Conf. & Interval] \\
\hline \multicolumn{7}{|l|}{ southafrica } \\
\hline gcfofgdp & 160.287 & 121.127 & 1.32 & 0.186 & -77.11752 & 397.6916 \\
\hline labourforce & .0014697 & .0002232 & 6.59 & 0.000 & .0010323 & .0019071 \\
\hline expgsofgdp & -96.77026 & 75.08195 & -1.29 & 0.197 & -243.9282 & 50.38765 \\
\hline exchratelc e & -636.5484 & 136.5113 & -4.66 & 0.000 & -904.1056 & -368.9912 \\
\hline Cons $_{\text {cons }}$ & -15799.84 & 1918.893 & -8.23 & 0.000 & -19560.8 & -12038.87 \\
\hline
\end{tabular}

\section{Appendix 2.}

\section{Result from statistics}

\section{Angola}

- summarize gdppercapitaus gcfofgdp labourforce expgsofgdp exchratelcuperusperi

> odaverage

\begin{tabular}{r|rrrrr} 
Variable & Obs & Mean & Std. Dev & Min & Max \\
\hline gdppercapi s & 21 & 2361.364 & 1903.461 & 374.1019 & 5327.149 \\
gcfofgdp & 21 & 17.20158 & 7.985498 & 8.779251 & 35.66087 \\
labourforce & 21 & 6669864 & 1275680 & 4899394 & 8844204 \\
expgsofgdp & 21 & 66.94511 & 14.89563 & 33.92706 & 89.62789 \\
exchratelc e & 21 & 58.67163 & 41.46488 & .0027502 & 120.0607
\end{tabular}




\section{Cameroon}

* (6 variables, 21 observations pasted into data editor)

- save "C:\Users\IYKE\Desktop\ang.dta", replace

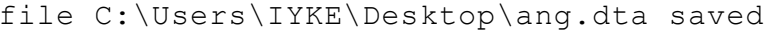

- summarize gdppercapitaus gcfofgdp labourforce expgsofgdp exchratelcuperusperi

$>$ odaverage

\begin{tabular}{r|rrrrr} 
Variable & Obs & Mean & Std. Dev & Min & Max \\
\hline gdppercapi s & 21 & 937.4165 & 279.7463 & 583.0948 & 1407.403 \\
gcfofgdp & 21 & 17.8823 & 2.273336 & 13.29641 & 20.73632 \\
labourforce & 21 & 7077473 & 1302497 & 5150486 & 9176788 \\
expgsofgdp & 21 & 20.95576 & 2.216597 & 16.03652 & 24.13013 \\
exchratelc e & 21 & 550.4143 & 82.23079 & 447.8053 & 733.0385
\end{tabular}

\section{Mauritius}

- summarize gdppercapitaus gcfofgdp labourforce expgsofgdp exchratelcuperusperi

$>$ odaverage

\begin{tabular}{r|rrrrr} 
Variable & Obs & Mean & Std. Dev. & Min & Max \\
\hline gdppercapi s & 21 & 6100.98 & 2409.296 & 3593.234 & 10153.94 \\
gcfofgdp & 21 & 24.17121 & 2.638474 & 18.10736 & 29.38878 \\
labourforce & 21 & 544680 & 31568.4 & 487564 & 592300 \\
expgsofgdp & 21 & 56.88531 & 6.091327 & 47.67717 & 68.45676 \\
exchratelc e & 21 & 27.86483 & 4.545398 & 17.38632 & 35.0567
\end{tabular}

\section{Namibia}

. * (6 variables, 21 observations pasted into data editor)

- save "C:\Users\IYKE\Desktop\ang.dta", replace

file C: \Users\IYKE\Desktop\ang.dta saved

- summarize gdppercapitaus gcfofgdp labourforce expgsofgdp exchratelcuperusperi

$>$ odaverage

\begin{tabular}{r|rrrrr} 
Variable & Obs & Mean & Std. Dev. & Min & Max \\
\hline gdppercapi s & 21 & 3533.53 & 1386.651 & 1716.896 & 5679.882 \\
gcfofgdp & 21 & 23.05497 & 4.613427 & 17.1007 & 34.18569 \\
labourforce & 21 & 734005.1 & 117455.5 & 537102 & 901859 \\
expgsofgdp & 21 & 44.64711 & 3.887784 & 39.81203 & 54.35427 \\
exchratelc e & 21 & 7.49426 & 2.239569 & 3.627085 & 12.88192
\end{tabular}




\section{Nigeria}

* (6 variables, 21 observations pasted into data editor)

- save "C:\Users\IYKE\Desktop\ang.dta", replace

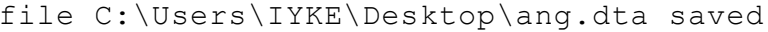

- summarize gdppercapitaus gcfofgdp labourforce expgsofgdp exchratelcuperusperi

$>$ odaverage

\begin{tabular}{r|rrrrr} 
Variable & Obs & Mean & Std. Dev & Min & Max \\
\hline gdppercapi s & 21 & 1219.897 & 1041.019 & 263.288 & 3203.244 \\
gcfofgdp & 21 & 10.25616 & 3.828029 & 5.467015 & 17.29074 \\
labourforce & 21 & $4.43 e+07$ & 6854802 & $3.43 e+07$ & $5.58 e+07$ \\
expgsofgdp & 21 & 32.89293 & 9.545257 & 10.6567 & 51.73036 \\
exchratelc e & 21 & 114.2215 & 50.94173 & 21.88442 & 192.4403
\end{tabular}

\section{South Africa}

. * (6 variables, 21 observations pasted into data editor)

- save "C: \Users\IYKE\Desktop\ang.dta", replace

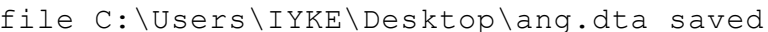

- summarize gdppercapitaus gcfofgdp labourforce expgsofgdp exchratelcuperusperi

$>$ odaverage

\begin{tabular}{r|rrrrr} 
Variable & Obs & Mean & Std. Dev. & Min & Max \\
\hline gdppercapi s & 21 & 5052.781 & 1712.428 & 2540.971 & 8077.967 \\
gcfofgdp & 21 & 18.99358 & 1.912346 & 15.74461 & 23.00551 \\
labourforce & 21 & $1.72 e+07$ & 1754251 & $1.38 e+07$ & $2.00 e+07$ \\
expgsofgdp & 21 & 28.21435 & 3.288827 & 22.1356 & 35.62244 \\
exchratelc e & 21 & 7.488403 & 2.224888 & 3.627085 & 12.75893
\end{tabular}




\section{Levin, Lin and Chu Unit Root Test}

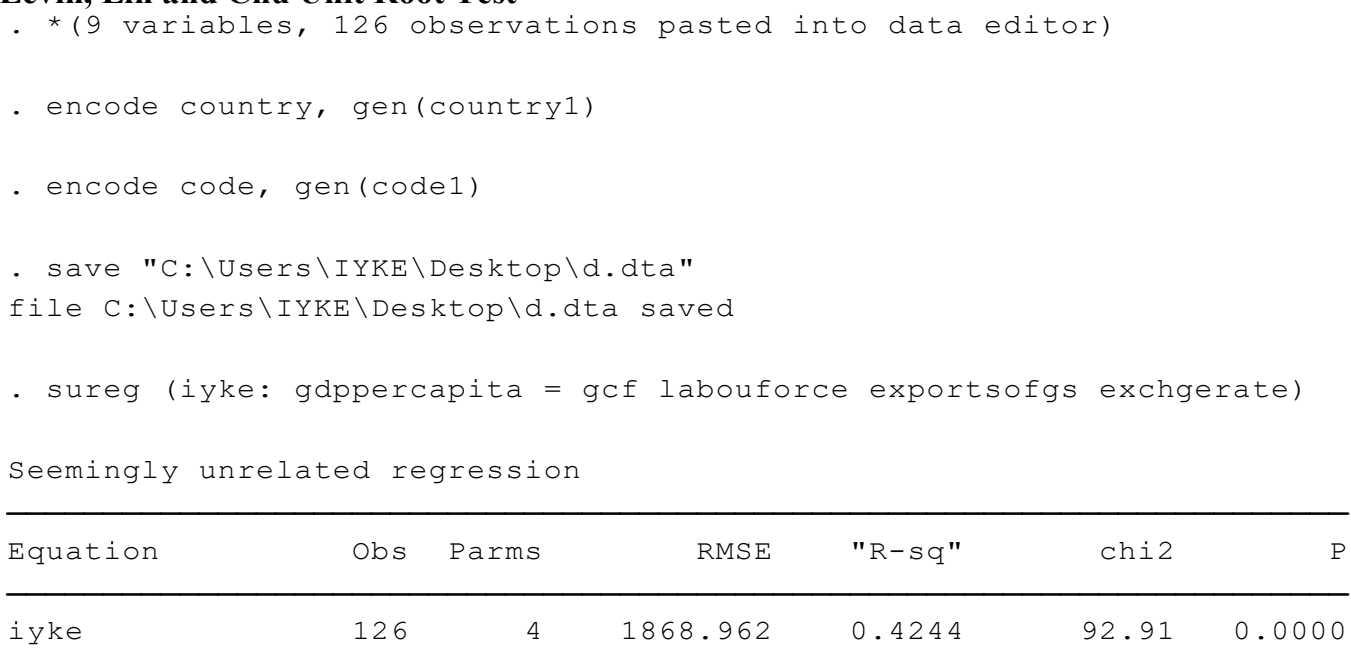

\begin{tabular}{|c|c|c|c|c|c|c|}
\hline gdppercapita & Coef. & std. Err. & z & $P>|z|$ & [95\% Conf. & Interval] \\
\hline \multicolumn{7}{|l|}{ iyke } \\
\hline$g C f$ & 92.48901 & 34.9373 & 2.65 & 0.008 & 24.01317 & 160.9648 \\
\hline labouforce & -.0000465 & .0000154 & -3.02 & 0.003 & -.0000766 & -.0000163 \\
\hline exportsofgs & -53.23663 & 12.42653 & -4.28 & 0.000 & -77.59217 & -28.88108 \\
\hline exchgerate & -7.72767 & 1.069768 & -7.22 & 0.000 & -9.824376 & -5.630965 \\
\hline - cons & 5283.336 & 1132.374 & 4.67 & 0.000 & 3063.923 & 7502.749 \\
\hline
\end{tabular}

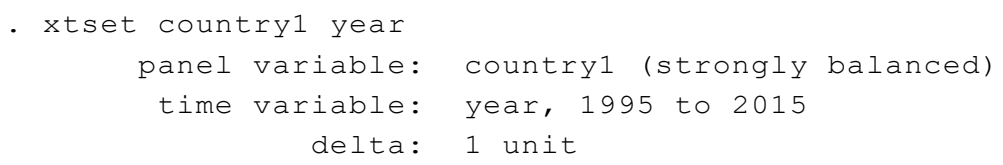

\begin{tabular}{llc} 
& Statistic & p-value \\
\hline Unadjusted $t$ & -2.0519 & \\
Adjusted $t^{*}$ & -0.2669 & 0.3948 \\
\hline
\end{tabular}


- xtunitroot llc gef, lags(1)

Levin-Lin-Chu unit-root test for gcf

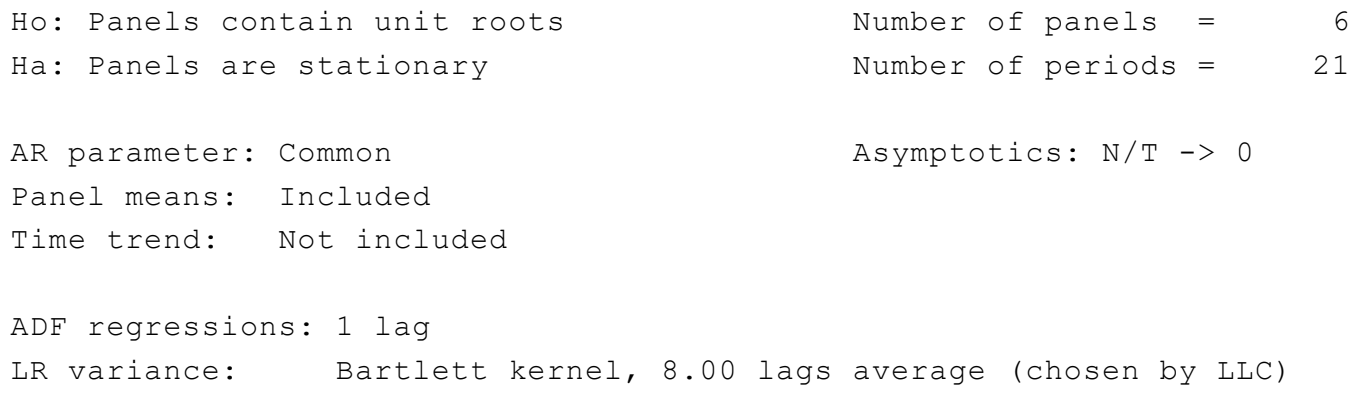

\begin{tabular}{llc} 
& Statistic & p-value \\
\hline Unadjusted $t$ & -3.2621 & \\
Adjusted $t^{*}$ & -0.5585 & 0.2883 \\
\hline
\end{tabular}

- xtunitroot llc labouforce, lags(1)

Levin-Lin-Chu unit-root test for labouforce

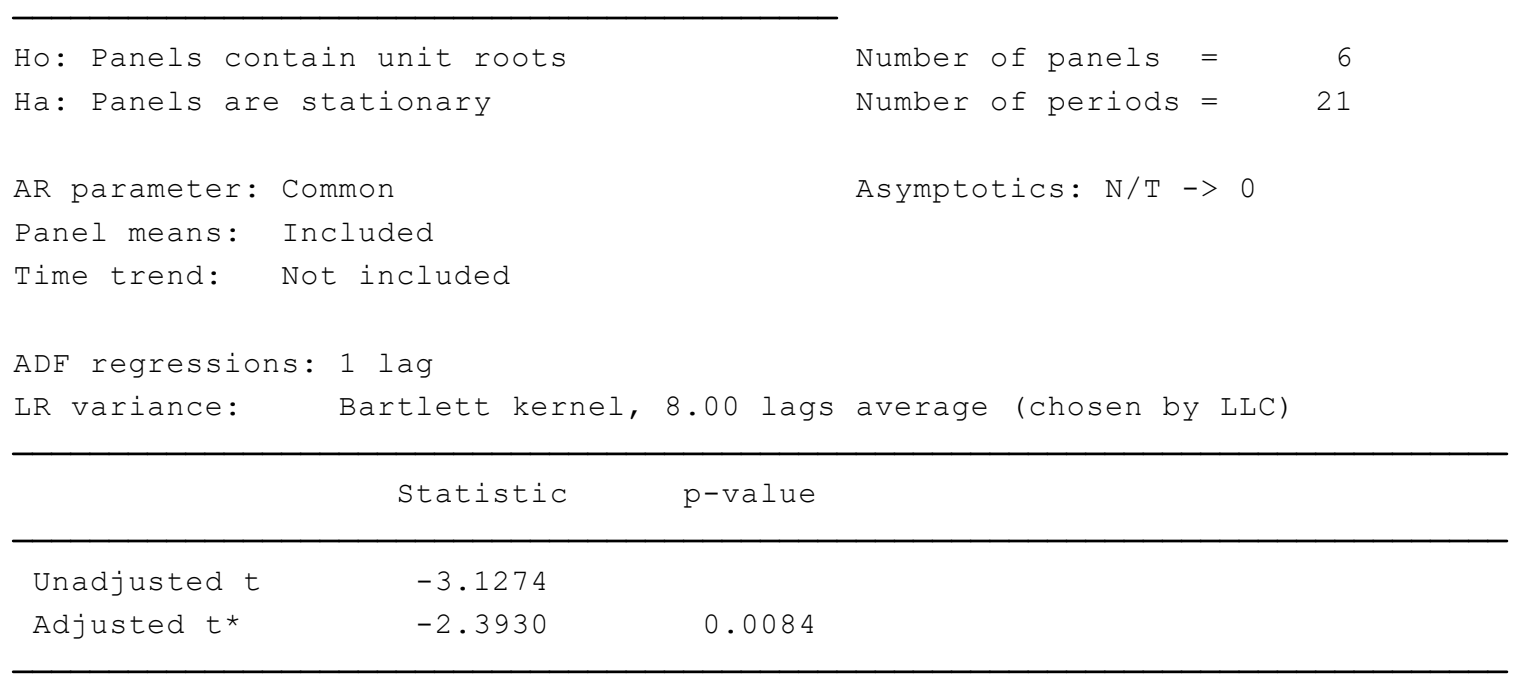


- xtunitroot llc exportsofgs, lags(1)

Levin-Lin-Chu unit-root test for exportsofgs

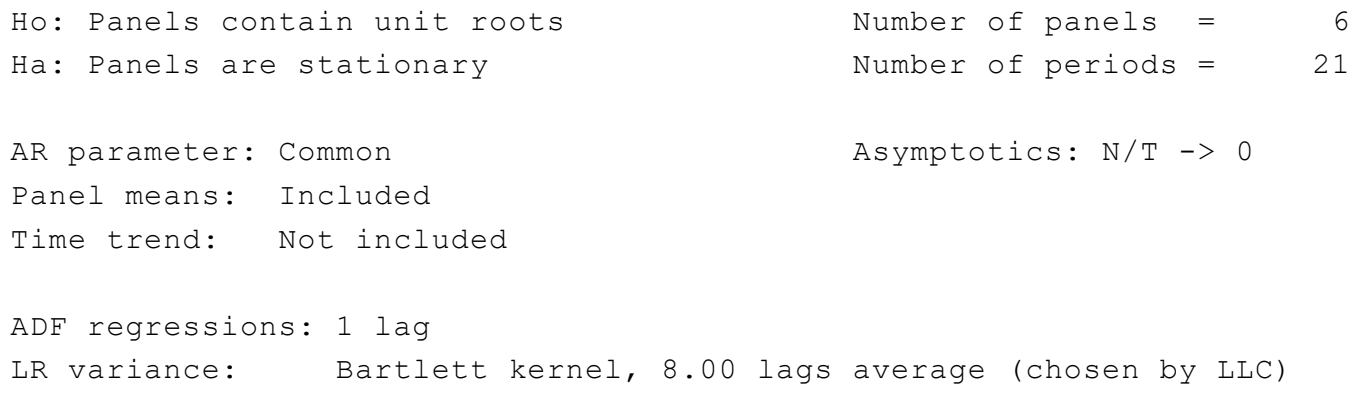

\begin{tabular}{llc} 
& Statistic & p-value \\
\hline Unadjusted $t$ & -4.9470 & \\
Adjusted $t^{*}$ & -2.1700 & 0.0150 \\
\hline
\end{tabular}

- xtunitroot llc exchgerate, lags(1)

Levin-Lin-Chu unit-root test for exchgerate

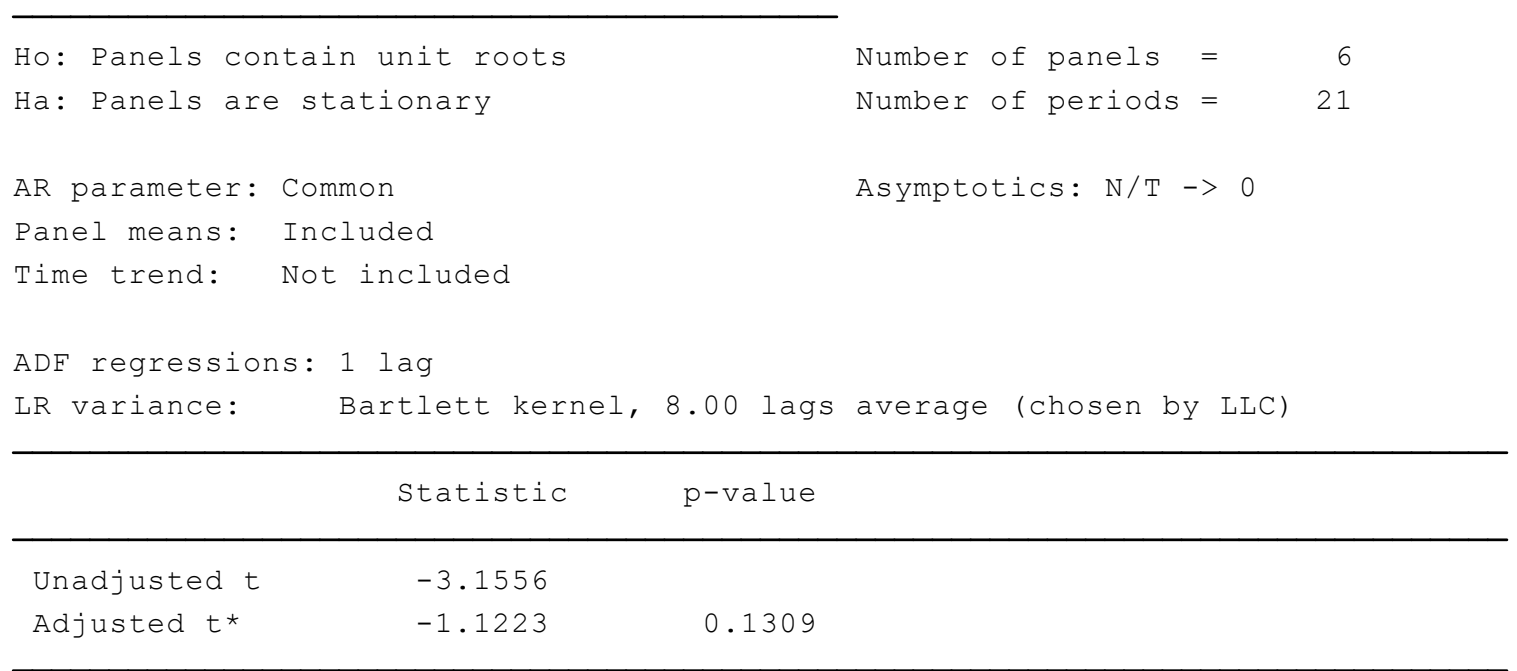




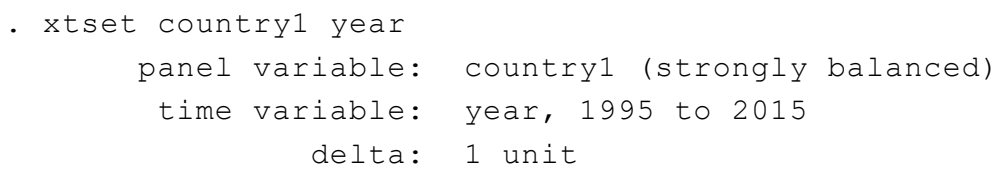

\begin{tabular}{|c|c|c|c|c|c|c|}
\hline \multirow[b]{2}{*}{ gdppercapita } & \multicolumn{3}{|c|}{ Panel-corrected } & \multirow[b]{2}{*}{$P>|z|$} & \multirow[b]{2}{*}{ [95\% Conf. } & \multirow[b]{2}{*}{ Interval] } \\
\hline & Coef. & Std. Err. & $\mathrm{z}$ & & & \\
\hline$g \subset f$ & 92.48901 & 35.49127 & 2.61 & 0.009 & 22.9274 & 162.0506 \\
\hline labouforce & -.0000465 & $9.75 e-06$ & -4.77 & 0.000 & -.0000656 & -.0000273 \\
\hline exportsofgs & -53.23663 & 8.948321 & -5.95 & 0.000 & -70.77501 & -35.69824 \\
\hline exchgerate & -7.72767 & .759735 & -10.17 & 0.000 & -9.216724 & -6.238617 \\
\hline _cons & 5283.336 & 967.5668 & 5.46 & 0.000 & 3386.94 & 7179.732 \\
\hline
\end{tabular}

